Section 3286

\title{
Teaching and Learning in Engineering Freshman Year
}

\author{
Julie Y.-Z. Wang, Mohammad Saifi \\ Potomac State College of West Virginia University \\ Keyser, WV 26726
}

\begin{abstract}
This paper describes the strategies and the methods that we have applied to the freshman engineering class at Potomac State College. The strategies for students to succeed the first year of engineering education include setting goals, having positive attitude, and teamwork. We have a variety of inside and outside classroom activities to maintain student interest. Creative thinking and logical reasoning methods are used throughout engineering problem solving and project designs. We have made progress in improving freshman year engineering education.
\end{abstract}

\section{Introduction}

Potomac State College of West Virginia University has a two-year engineering program. The program is articulated with the four-year engineering program at West Virginia University. Most students will transfer to the university after they complete an associate degree in engineering. Although we have small classes, and students can get more attention and help from instructors, the retention problem still exists. Since there is no prerequisite for the first introduction course in engineering, students come to engineering class with different math levels and computer skills. Student learning and retention, particularly for the freshman year, are the priorities of our program. Our goal is to help freshman engineering students understand engineering profession, select their major, learn creative thinking and the engineering design process, prepare for the upper level courses, and enhance their engineering and computer skills. Our strategies and methods follow.

\section{Strategies}

\section{$\underline{\text { Setting Goals }}$}

We help students set one-year academic goals, four-year academic goals, and career goals along with the process of learning. Students realize that engineering is a challenge and a rewarding career; it is a lifetime learning process. In order to reach their goals, they should make a plan at each stage of learning. We have one-to-one meetings with students at registration time; we check their work, provide them information, identify the problems, and help them make a decision. 


\section{Having Positive Attitude}

Freshman engineering students need to build confidence, need commitment to schoolwork, and need to organize their time and personal life. Some students have part time jobs, but take full time class loads. It is difficult for them to concentrate on school work. If a student is not ready for college and can not handle the situation around him/her, the student will fail. We use the "Academic Success Skills Survey" ${ }^{1}$ as an assessment tool. The questions on the survey tell students what the positive attitude is. We did both individual and team surveys the first day of the class and also at the end of the semester. From the students' response to the survey, we can measure how their attitude has changed.

The results show that the students have made significant changes in the following aspects: -" I recognize the importance of goal setting and I have clear academic goals."

-" I am highly motivated through a clear understanding of the rewards and opportunities graduating in my chosen major will bring to my life."

-" I make effective use of my peers by frequent sharing of information and regularly engaging in group study and collaborative learning."

The less significant changes are the following aspects:

-"I keep up with my classes by mastering the material presented in the last class meeting before the next class meeting."

-"I devote an appropriate amount of time and effort to my studies."

The survey shows that some students did not devote enough time and effort to study. This is also the reason why students have to withdraw from the classes. We have regulations and a class attendance policy, and we give students a warning priori to suspension from the class; however, students missing classes and not completing homework continues.

\section{Teamwork}

We divided the class into several student design teams. The teams are not only for project design, but also for collaborative learning. Through team projects, team presentation, and team evaluation, students gather ideas and share their expertise, they support each other and create a collaborative learning environment. The advantages to teamwork are obvious. On the other hand, it is difficult to be certain that members of the team all deserve the same grade. There is problem associated with fairness. We usually assign individual work as a part of project and require individual project reports based on the teamwork.

\section{Mathematics Preparation}

Mathematics plays an important role in engineering study. One of the problems in freshman engineering class is the weakness in mathematics. We try to place students in the appropriate math level based on the college placement test. Any student who does not qualify to take calculus has to make up the lower level math courses before entering the engineering program. Students have study group to help each other, and we monitor students' progress in math courses. In the future, we will schedule a math help section as a requirement in freshman engineering 
class to ensure that students have time to complete homework and are ready for the next math class.

\section{Methods}

\section{Creative Thinking}

"It is important for us to realize that creativity can be introduced, taught and learned within a course that has other objectives as its major goals." 2 Since there is no prerequisite for the first class in engineering, students are required to bring their "brain" to the class. Student teams are given open-ended projects related to different engineering field, they have to brainstorm to answer a series of questions about why, when, what, where, how. They do research and create ideas by comparison, analysis, and synthesis. The teams are able to focus on one or two best ideas and develop a detailed plan and then find the best solution to solve the problem. Students will give an individual final project report, a team project presentation, and peer evaluations.

\section{Logical Reasoning}

We teach logical reasoning and thinking methods to solve problems related to engineering principles. The textbook written by Wales and Stager $^{3}$ gives the examples, step by step, to show how engineering problems are solved logically. Students are able to complete a series of equations with correct calculations and engineering units. We also introduce the logical thinking method into students' report writing and engineering graphics processes.

\section{$\underline{\text { Filed Trips }}$}

We arranged several field trips to industrial companies around this area and met with the engineers there. Students found out what daily jobs there are for engineers and what future career they could have.

Students commented, that "You never stop learning in this profession and it is a very interesting field to be a part of and it is a promising career with a lot of future, because people will always try to improve what they have." "Engineering is a challenging and fulfilling career." "The engineers inspired me to work harder in school, you have to know the engineering basics very well, learn engineering skills and participate in business".

We also invite our graduates back to meet with current students. They use their own experience to show their success. An advice given by them is "Quit is the easiest thing you could do and you could do it anytime. So don't give up!"

\section{Summary}

With student-centered teaching and learning and with a variety of learning activities inside and outside the classroom, students increase their confidence and interest in pursuing an engineering career. Students who successfully complete their freshman year usually can do well in the sophomore year. Most of our graduates have successfully completed their four-year program at 
the University. We still have a lot of work to be done on retention; we will continue to learn new methods and experiences from freshman engineering community.

\section{Bibliography}

1. Landis, R. B., Studying Engineering- A Road Map to a Rewarding Career, Discovery Press, 2000.

2. Nee, J. G., Proceedings of NSF Sponsored Workshop on Introductory Engineering Design, Engineering Design Graphics and Technical Graphics Problem Solving, the University Press of Central Michigan University, 1999.

3. Wales, C.E. and R.A.Stager, "Thinking with Equations - Problem Solving in Math and Science, West Virginia University, 1990.

\section{JULIE Y.-Z. WANG}

Julie Yi-Zun Wang is currently an Associate Professor in the Engineering Department of Potomac State College of West Virginia University. She received her M.S. and Ph.D. in Mechanical Engineering from Lehigh University. She is a registered Professional Mechanical Engineer in Pennsylvania and is actively involved in research with industry and research in the fields of computational fluid mechanics, heat transfer, and thermodynamics. She teaches freshman engineering and other engineering courses.

\section{MOHAMMAD SAIFI}

Mohammad Saifi currently is a Professor of Electrical Engineering and Computer Science at Potomac State College of West Virginia University. He received both a B.S. and M.S. in Electrical Engineering and an M.S. in Industrial Engineering, all from the University of Arkansas. He teaches courses in Electrical Engineering and Computer Science. 